\title{
Building a system for efficient use of resources in construction
}

\author{
Dmitry Kozhevnikov ${ }^{1, *}$ \\ ${ }^{1}$ Moscow State University of Civil Engineering, Yaroslavskoeshosse, 26, 129337, Moscow, Russia
}

\begin{abstract}
The article studies various aspects of building a system for efficient use of resources in construction and develops a model for estimating resource flows in construction. It has been proved that construction work cannot be organized without proper material resources: raw materials, construction materials, fuel, energy, pre-fabricated products, etc. It has been determined that the model for estimating the resource flows in construction should take into account the volume of resource consumption, i.e. resource consumption per unit of specific demand for their consumption, taking into account the total amount of resources consumed by a construction firm, and their cost.
\end{abstract}

\section{Introduction}

The construction industry's first and foremost objective is fulfilment of all national economic functions, specifically: creation of fixed assets and production capacities integrating advanced technologies of scientific and technological progress; rapid modernization of existing enterprises using progressive technology; comprehensive and timely realization of social programs; provision of high quality construction products; shortening the construction timeframes and increasing the investment efficiency.

\section{Analysis of recent research and publications}

Particular problems related to the management of efficient use of resources were reviewed in the works of foreign and domestic scientists, such as A.I. Amosh, V.P. Babich, A.V. Batura, N.G. Belopolsky, S.L. Denisyuk, V. Klimanov, T. Rubinstein, M.I. Nizhniy, M. Kolosovsky, S.I. Doroguntsov V.L. Dikan, N.N. Lukyanchikov, V.V. Maksimova, I.M. Potravnevnevy, M.A. Hvesik, E.V. Khlobistov, M.I. Faschevsky, L.G. Chernyuk, M. Chumachenko, I. B. Shvets, etc. Foreign researchers working at the problem of resource saving are K. Boulding, A. Granberg, L. Kantoroch, D. McIntosh, D. Meadows, Mr. Odum, E. Odum, U. Rostow, R. Solow, T. Titenberg, G. Taylor, J. Forrester and others.

The purpose of this article is to build a system for the efficient use of resources in construction and to develop a model for estimating the resource flows in the construction industry.

\footnotetext{
${ }^{*}$ Corresponding author: linstroy@mail.ru
} 


\section{Research methodology and results}

The resource-saving policy of a given enterprise can be generally viewed as a chronological sequence of several investment projects being implemented. Funding is the first issue that arises when making an investment decision.

The choice of a right direction for implementing a planned project requires development and evaluation of the existing alternatives. The main options are modernization of existing fixed assets or the acquisition of new ones.

When deciding to purchase new equipment, one must choose between purchasing domestic or imported equipment. The next step is to decide on how to compare these alternatives. It is also necessary to take into account that, most often, this is inherently an ecological investment, the specificity of which lies in the difference of effects that are achieved in the types of effects considered, and the methods for determining them. The organization of construction work in a construction firm is impossible without material resources: raw materials, construction materials, fuel, energy, pre-fabricated products, etc.

The construction industry enterprises' needs in material resources can be satisfied in two ways: extensive and intensive.

The extensive way implies an increase in production and manufacture of material resources and creates additional costs. Moreover, production growth alongside the existing technological systems has resulted in the natural resource depletion rates and environmental pollution levels going way beyond permissible limits.

Therefore, the firm's needs in material resources should be satisfied through a more economical or intensive use of the resources during production. The industrial reproduction of raw materials today has generally a great impact on production in the construction industry. The economic deficit of natural resources, an increase in waste of resources and in the rate of production of construction products from secondary raw materials made it obvious that the issue of the material resources reproduction will be one of the main issues related to the increasing of the efficiency of resource saving. The main aspect of enterprise resource saving is the prevention of growth and even the reduction of situational costs that arise during the work. This will significantly save material, labor and financial resources, as well as reduce the losses of other types of resources such as human, environmental, etc. in most cases.

Resource-saving at a production enterprise implies timely detection and targeted impact on factors that increase the expenditure of material and labor resources during the operation of equipment. These processes can be ensured by monitoring the technical condition of the equipment and ensuring the effective actions by personnel related to the resource conservation. Modern systems of construction enterprises management include certain steps to determine the tools for improving the efficiency of resource saving. The qualitative management of construction industry enterprises requires the development of a model showing the resource intensity of construction products. The model for estimating resource flows in construction production should take into account the volumes of consumption of production resources, i.e. the amount of resources per unit of specific demand for their consumption, taking into account the total amount of resources consumed by a construction firm, and their cost:

$$
O_{p}=\sum_{i=1}^{n} B_{p} * N_{i \rightarrow n} * C_{p}
$$

where $B_{p}$ - expenses of a specific type of material resources per unit of a specific type of construction products, natural units;

$N_{i \rightarrow n} \rightarrow \mathrm{n}$ - quantity of the product, natural units;

$C_{p}$ - price per unit of material resources, rubles 
Studying the construction companies' experience in the measurement of resource intensity, we developed a model that allows us to analyze various options for resource flows in the manufacture of construction products, and to determine the most economically viable options in terms of resource intensity.

This model also allows determining the optimal scale of use of specific types of material resources for the production of construction products:

$$
\left\{\sum_{i=1}^{n} B_{p} * N_{i \rightarrow n} * C_{p}\right\} \rightarrow \min \left\{\sum_{i=1}^{n} B_{p(a)} * N_{i \rightarrow j} * C_{p(a)}\right\},
$$

where $B_{p(a)}$ - expenses of a specific type of material resources per unit of a specific type of construction products, natural units.;

$N_{i \rightarrow j}$ - quantity of units of specific product which satisfies the need

$N_{i \rightarrow n}$, natural units;

$C_{p(a)}$ - price per unit of an analogous material resource, rubles.

This model can be applied in construction firms with different forms of ownership since its basic idea of reducing the resource intensity of construction products can be universally expressed.

The application of a logistics concept plays a special role in resource saving, especially in the construction industry. Such a concept should aim to optimize certain operations related to the rational use of material resources.

The movement of resources always assumes storing them somewhere. These are normally warehouses whose smooth operation affects the optimum movement of material flows and, eventually, a construction firm's efficient operation. The logistic functions of warehouses are implemented in carrying out separate logistical operations (table 1).

Table 1. Logistic operations and functions

\begin{tabular}{|c|c|c|c|c|}
\hline No & \multicolumn{4}{|c|}{ Logistic operations and functions } \\
\hline $\mathrm{I}$ & \multicolumn{3}{|c|}{ Functions } & \multirow{2}{*}{ Operations } \\
\hline II & Basic & Key & Supporting & \\
\hline 1. & supply & quality control & warehousing & loading \\
\hline 2. & production & $\begin{array}{l}\text { procurement } \\
\text { management }\end{array}$ & $\begin{array}{l}\text { cargo } \\
\text { handling }\end{array}$ & unloading \\
\hline 3. & distribution & transportation & $\begin{array}{l}\text { protective } \\
\text { packaging }\end{array}$ & packing \\
\hline 4. & - & $\begin{array}{l}\text { inventory } \\
\text { management }\end{array}$ & $\begin{array}{l}\text { ensuring the } \\
\text { return of } \\
\text { cargo }\end{array}$ & freight forwarding \\
\hline 5. & - & $\begin{array}{l}\text { managing order } \\
\text { proceures }\end{array}$ & $\begin{array}{l}\text { provision of } \\
\text { spare parts } \\
\text { and service }\end{array}$ & cargo transportation \\
\hline 6. & - & $\begin{array}{l}\text { operational } \\
\text { management of } \\
\text { production }\end{array}$ & $\begin{array}{l}\text { waste } \\
\text { collection }\end{array}$ & $\begin{array}{l}\text { acceptance and } \\
\text { release of cargo from } \\
\text { the warehouse }\end{array}$ \\
\hline 7. & - & price formation & - & transshipping \\
\hline 8. & - & - & - & sorting \\
\hline 9. & - & - & - & cargo assembling \\
\hline 10. & - & - & - & $\begin{array}{l}\text { collection, storage, } \\
\text { transfer of } \\
\text { information about } \\
\text { cargo }\end{array}$ \\
\hline 11. & - & - & - & settlements with \\
\hline
\end{tabular}




\begin{tabular}{|c|c|c|c|c|}
\hline No & \multicolumn{4}{|c|}{ Logistic operations and functions } \\
\hline I & \multicolumn{3}{|c|}{ Functions } & \multirow{2}{*}{ Operations } \\
\hline II & Basic & Key & Supporting & \\
\hline & & & & suppliers and buyers \\
\hline 12. & - & - & - & cargo insurance \\
\hline 13. & - & - & - & $\begin{array}{l}\text { transfer of ownership } \\
\text { of cargo }\end{array}$ \\
\hline 14. & - & - & - & $\begin{array}{l}\text { customs clearance of } \\
\text { cargo }\end{array}$ \\
\hline 15. & - & - & - & Etc. \\
\hline
\end{tabular}

When choosing and arranging a warehouse, the first thing to be determined is the type of storage, i.e. the method for placing goods in the warehouse, taking into account the purpose of the stocks, financial potential of the construction firm, assortment, physical volume of basic and auxiliary materials, specific storage requirements, mechanization levels, etc. The creation of stocks always assumes incurring certain costs. The main costs associated with creating and managing stocks include:

- Immobilization of financial resources;

- Costs on maintenance of specially equipped premises;

- Costs on remuneration of special personnel;

- Losses from damage and theft.

The presence of stocks at a construction firm incurs expenses, but the absence of stocks is expenses, too, expressed in the form of various losses. The main types of losses associated with the absence of stocks include:

- Losses from production downtime;

- Losses from material being absent in stock at high demand;

- Losses from basic and auxiliary materials being purchased at higher prices, etc.

Thus, the main reasons for creating stocks in the construction industry are:

1) fluctuations in demand for construction products, which cannot be accurately predicted;

2) fluctuations in demand for basic and auxiliary materials;

3) reduction in costs associated with the delivery and storage of large orders;

4) probability of delivery deadlines being violated;

5) minimizing production downtime caused by the absence of materials;

6) simplification of the production management flow, because the availability of stocks allows relaxing the requirements to the level of consistency of production processes at different sites, and consequently, the corresponding management costs.

Thus, the reasons listed above show that the smooth and efficient operation at construction firms requires the organization of stocks, but their amounts should not exceed a certain optimum value. Research has been conducted and its conclusions suggest that the main functions when managing stocks at construction firm are:

- Forecasting the possible use of stocks of basic and auxiliary materials;

- Monitoring the actual use of stocks of basic and auxiliary materials and finished construction products;

- Monitoring actual expenses for the replenishment of stocks of basic and auxiliary materials and finished construction products;

- Monitoring the time needed to create stocks through regulation or production.

One should use the following indicators to evaluate properly the efficiency level of inventory management: 
- Volume of stocks of basic and auxiliary materials and finished construction products, characterizing the availability at the construction enterprise of stocks for a certain date and determines how many days this stock will last;

- Rate of turnover of reserves of basic and auxiliary materials and finished construction products as a ratio of the volume of stocks of basic and auxiliary materials and finished construction products to the volume of finished construction products sold for a certain period;

- Duration of the stock turnover is the time interval between the receipt of the basic and auxiliary materials at the construction company and the sale of finished construction products.

The inventories at construction firms should be managed on the basis of an algorithm which includes two large blocks:

- the first block is the creation of an information base containing the normative and actual level of stocks by dividing into separate types of material resources, taking into account their importance, that is, distribution by groups and importance. According to the importance of material resources, demands for the efficiency and likelihood of control over the stocks of material resources are made;

- The second block is the formation of a bank for models of management of material resources stocks.

The considered methods of control over the state of stocks of material resources, taking into account the specifics of the construction industry, made it possible to determine the important features of material resources management and storage at the enterprises of the construction industry of the Russian Federation.

The economic effect of the optimization of the resource intensity of the products in the construction industry will be caused by reducing the costs of construction products. In this case, the effect in question will be accounted for by the difference in the cost of construction products;

- in case of unchanged and sometimes at a higher cost of construction products, but with an increase in the consumer effect.

In this case, the economic effect will be measured by the gain in the unit cost of the consumer effect;

- in case of a fundamentally new consumer effect.

Such an effect is formed in the market depending on the price that received public recognition in this market.

\section{Conclusion}

In order to ensure a gradual increase rate for implementing resource-saving technologies, a set of conditions of complex nature need to be observed. These include the growth rate and speed of recovery of production, scientific and technical and labor potential, and the scope of other activities pursued by construction firms. If a construction firm wishes to obtain the best results of resource saving, it needs to conduct a comprehensive study of ways to improve the availability of material resources to construction firms, to determine the key principles of resource saving of production of construction firms and to stimulate greater efficiency in resource conservation.

Forming an efficient methodology for planning and optimizing the annual production program is an extremely important issue. It is obvious, however, that the General Contractor should control and integrate the works not only within its own program, but also among subcontractors. With regard to the considered optimization method, we can say that the development of a similar methodology for different types of organizations and specializations in the construction industry makes it possible to identify functional 
dependencies and analytically calculate the amount of work that is permissible for transfer to a subcontractor without risks of loss of control over construction sites using mathematical tools and statistical methods. And vice versa - the minimum necessary volume of construction and installation works for the General Contractor in order to ensure the management function and resource support of the main work flow.

\section{References}

1. V.Y. Shevchuk, Conditions for effective investment in construction (Stroitel, Moscow, 2011)

2. A.V. Grishchenko, Analysis of material resources of an enterprise, http: // www.aup.ru/books/m67/4.html (2016)

3. V.P. Babich, State industrial policy (HNU in the name of V.N. Karazin, Kharkiv, 2013)

4. E.N. Lomkov, Economical and mathematical models of production management (theoretical aspects) (VolgGTU, Volgograd, 2015)

5. S.M. Ivanyuta, Practice and experience: scientific and practical journal 2, 33-35 (2012)

6. D.A. Soloviev, Management of innovative projects of a construction company in the field of resource saving. Thesis. PhD: 08.00.15 "Economy and management of a national economy (management of innovations and investment activities)" (2015) 